\title{
ANALYSIS OF Psidium araça RADDI CULTIVATED IN THE RECIFE METROPOLITAN REGION/BRAZIL
}

\author{
M.R. F. PADILHA*, N.K.S. SHINOHARA, E.P.R. FERREIRA, R.M.M. PIMENTEL, S.A.C. ANDRADE \& F.H.P.C. de \\ OLIVEIRA \\ Universidade Federal Rural de Pernambuco \\ fatpadilha@ig.com.br
}

Artigo submetido em 26/04/2016 e aceito em 17/12/2019

DOI: $10.15628 /$ holos.2019.4474

\section{ABSTRACT}

New researches have stimulated a large reevaluation of species with regards to the use of fruits from native plants. Araçá (a small Brazilian guava-like fruit) is found scattered in the wild in Pernambuco/Brazil. There is a scarcity of detailed studies on such regional fruit trees, especially the Psidium araça Raddi species, whereas there is an enormous possibility to explore the potential offered by these fruits, such as in the field of gastronomy, where the search for new ingredients and exotic flavors associated with functional properties has been increasing. This article aimed to evaluate the physical, physicochemical and taxonomic characterization of araçá obtained from different
\end{abstract}

agricultural regions of Pernambuco in order to investigate the possibility of developing new products from this native fruit. The taxonomic identification confirmed that all collected material belonged to the species P. araçá Raddi. An average weight of $7.45 \mathrm{~g} /$ fruit was observed. With respect to $\mathrm{pH}$, values between 3.17 and 3.48 were found, and the acidity as a percentage of citric acid was on the order of $0.96 \%$ to $0.99 \%$. It was shown that the $P$. araça Raddi fruit has a desirable quality for the food industry, presenting excellent conditions for the development of formulations of high commercial value and promising application in the national gastronomy.

KEYWORDS: araçá fruit, taxonomy of native fruits, natural ecosystems, gastronomy.

\section{ANÁLISE DE Psidium araça RADDI CULTIVADA NA REGIÃO METROPOLITANA DO RECIFE/BRASIL}

\section{RESUMO}

Novas pesquisas tem estimulado uma larga reavaliação de espécies com relação ao uso de frutos de plantas nativas. Araçá é encontrada é encontrada espalhada em estado selvagem em Pernambuco/Brasil. Há uma escassez de estudos detalhados sobre tais árvores de frutas regionais, especialmente o Psidium araça Raddi, ao passo que há uma enorme possibilidade de explorar o potencial oferecido por esses frutos, como no campo da gastronomia, onde a busca de novos ingredientes e sabores exóticos associados a propriedades funcionais tem aumentado. Este artigo teve como objetivo avaliar a caracterização física, físico-química e taxonômica de araçá obtidos de diferentes regiões agrícolas de Pernambuco, a fim de investigar a possibilidade de desenvolver novos produtos a partir desta fruta nativa. A identificação taxonômica confirmou que todo o material recolhido pertencia à espécie $P$. araça Raddi. Observou-se um peso médio de 7,45 g / fruto. No que diz respeito ao $\mathrm{pH}$, valores entre 3,17 e 3,48 foram encontrados, e a acidez em termos de percentagem de ácido cítrico foi da ordem de 0,96\% a 0,99\%. Foi demonstrado que a $\mathrm{p}$ araçá Raddi fruta tem uma qualidade desejável para a indústria alimentar, apresentando excelentes condições para o desenvolvimento de formulações de elevado valor comercial e aplicação promissora na gastronomia nacional.

PALAVRAS-CHAVE: araçá, taxonomia de frutas nativas, ecossistemas naturais, gastronomia 


\section{INTRODUCTION}

Large concerns over climate change have caused many people to adopt green habits. The degradation of flora, which is important in the maintenance of fauna, has become a threat to the survival of man, thus encouraging human measures that promote the preservation of natural ecosystems. Many exotic fruits that are used regionally, including for medicinal purposes, are also part of the diet of the population but have not been well studied. Studies have provoked a large reevaluation of these species to gather information on the use of fruits from native plants (KINUPP, 2014).

Psidium araça Raddi, a synonym of $P$. guineense Sw. (MORTON, 1987), also known as araçá-azedo or araçá-do-campo in Portuguese, is a spontaneously occurring shrub native to South American and belonging to the Myrtaceae family. Individuals of this species reach heights varying from seventy centimeters to ten meters, have a sparse canopy, and bear fruits possessing a smooth flakey peel that are generally harvested between February and April (DONADIO, 2002). However, the production of these fruits may occur during the entire year (GONZAGA NETO \& BEZERRA, 2000). They grow in clayey, sandy soils and present good potential for development in poorly drained soils (SILVA \& TASSARA, 1996).

Currently, araçá is systematically cultivated in small areas of the Brazilian state of Rio Grande do Sul. Interest in the species has expanded due to the discovery of its high nutritional value, with a presence of vitamin $C$ that is three to seven times greater than that found in other citrus fruits (MANICA, 2000). Pioneering research with this fruit has resulted in the selection and use of genetic material with important productive characteristics (VOLTOLINI et al., 1996). The hybrid cultivars of the araçá plant available from Embrapa Clima Temperado include the "Yacy" with a yellow peel and "Irapuã" with a red peel. These cultivars are planted in commercial orchards, but only on a small scale (FRANZON, 2004).

Despite the significant dispersion of araçá in areas with tropical climates (FRANZON, 2004), the araçá has undergone little economic exploration (CLEMENT, MULLER \& FLORES, 1982; BEZERRA et al., 1990). However, it has enormous potential due to the possibility of either commercializing the fruit in natura or promoting industrialization due to the ease of development of the species in poor soils; at two years of age, large fruits that are rich in pulp and aroma can begin undergoing production, which is ideal for the grower (CAVALCANTE, 1976).

In the Brazilian state of Pernambuco, fruit species such as $P$. araçá Raddi are encountered as dispersed in the wild. However, in 1989, the Empresa Pernambucana de Pesquisa Agropecuária (Agricultural Research Company of Pernambuco - IPA (1987) began a project of genetic prospection and germplasm collection from native and exotic fruit species, including the araçá plant, by means of seminiferous dissemination (sexual propagation) with the objectives of analyzing and characterizing superior specimens to establish commercial cultivars and also preserving those threatened by extinction (BEZERRA et al., 1990; REIS SILVA et al.2008).

Studies are needed due to the scarcity of in-depth information regarding regional fruit species, especially $P$. araçá Raddi, and the large potential contributions offered by these fruits to 
gastronomy, where the search for new ingredients and exotic flavors is constantly growing. The objective of this study was the physical, physicochemical and taxonomic characterization of the araçá encountered in the metropolitan region of Recife, Brazil, intended to stimulate the investigation of the possibly economically viable products based on this native fruit.

\section{MATERIALS AND METHODS}

The fruits (Figure 1) were harvested during the period from August to September of 2014 at three different locations in the state of Pernambuco: a) in the fruit plantation near the Terminal Integrado de Passageiro (TIP) in Recife, Curado district; b) in the municipality of Vitória de Santo Antão; and c) on the beach of Catuama, in the municipality of Goiana, 72 km from the capital of Recife.

From each of the three locations, three samples of whole, ripe fruits presenting no physical damage were randomly collected (average of $0.5 \mathrm{~kg}$ per sample). Immediately after harvest, the fruits were transported to the Food Laboratory of the Department of Rural Technology (DTR) of the Universidade Federal Rural de Pernambuco (UFRPE), where they were sorted and cleaned.

For taxonomic identification, samples were collected and sent to Professor Vasconcelos Sobrinho Herbarium (PEUFR) of the Department of Biology, College of Botany, UFRPE.
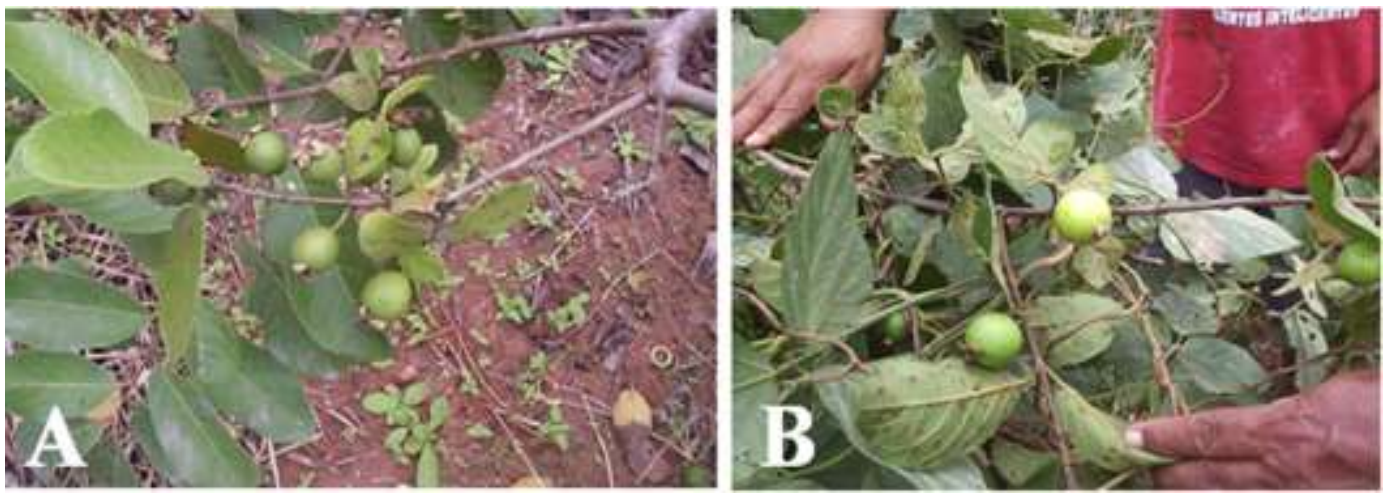

Figure 1. A-B. Vines of Psidium araça Raddi: A. Those in individuals established in Vitoria de Santo Antão, Pernambuco; B. Those in individuals established in Curado, Pernambuco.

The samples were stored at $-18 \pm 2{ }^{\circ} \mathrm{C}$ in a vertical freezer until the initial analyses; low storage temperatures delay disorders in the internal structure of the araçá fruit (ARAÚJO et al., 1996).

For physical analyses, 40-g portions of the fruits were separated and evaluated individually. Entire fruits were weighed on a semi-analytical digital scale, and the pulp yield was obtained by the ratio between the weight of a whole fruit and that of its pulp. The pulps of the fruits were ground in an industrial blender, forming a homogeneous sample that was analyzed with three repetitions. 
Determinations of the moisture content, acidity and total soluble solids (TSS) were performed according to the methodologies utilized by the Adolf Lutz Institute (2005). The data were evaluated via an analysis of variance (ANOVA) using the Duncan test for comparison at the level of $5 \%$ significance. To verify the relationship between the originating locations of araçá and the physicochemical parameters, a Principal Component Analysis (PCA) was performed. The data were evaluated using the Statistica for Windows 6.0 program.

\section{RESULTS AND DISCUSSION}

All samples collected were identified as belonging to the species Psidium araça Raddi. The araçá species under study (Table 1) presented a pH varying from 3.17 to 3.48 and elevated acidity with a percentage of citric acid between $0.96 \%$ and $0.99 \%$; such $\mathrm{pH}$ values provide a greater intrinsic barrier against biological contamination of the foods, making araçá a desirable fruit for the food industry (GOMES, 2007). In another study by Chisté et al. (2008), when formulating a jelly from araçá-boi, they encountered a citric acid acidity percentage of $0.49 \%$ and a $\mathrm{pH}$ of 3.40 . Thus, the acidity of the fruit is directly related to the species involved, which causes variations in this index even within the same genus, as is the case for Psidium. According to Oliveira et al. (2005), fruit from the araçá plant possesses a flavor similar to that of guava, but it is slightly more acidic and has a more accentuated aroma.

Table 1: Physicochemical characterization of fruits Psidium araça Raddi in natura from different locations in the state of Pernambuco.

\begin{tabular}{cccccc}
\hline Locations & Weight (g) & Humidity (\%) & pH & Acidity*(\%) & TSS (\%) \\
V & $6,30 \pm 0,58 \mathrm{~b}$ & $73,98 \pm 0,18 \mathrm{a}$ & $3,32 \pm 0,05 \mathrm{~b}$ & $0,98 \pm 0,006 \mathrm{a}$ & $9,57 \pm 0,06 \mathrm{a}$ \\
$\mathrm{CA}$ & $6,95 \pm 0,89 \mathrm{~b}$ & $62,52 \pm 2,03 \mathrm{~b}$ & $3,48 \pm 0,0 \mathrm{a}$ & $0,96 \pm 0,006 \mathrm{~b}$ & $9,77 \pm 0,06 \mathrm{a}$ \\
$\mathrm{C}$ & $9,11 \pm 1,21 \mathrm{a}$ & $73,92 \pm 0,0 \mathrm{a}$ & $3,24 \pm 0,12 \mathrm{~b}$ & $0,99 \pm 0,006 \mathrm{a}$ & $10,00 \pm 0,0 \mathrm{a}$ \\
\hline
\end{tabular}

TSS: Total soluble solids (\%); V: Vitória de Santo Antão; Ca: Catuama (coast); C: Curado; *:As percentage of citric acid. Averages in the same row followed by the same letter do not differ at the significance level of $5 \%$ by the Duncan test.

It can be observed in Table 1 that the moisture content of the araçás from Catuama (Ca) differed significantly $(p<0.05)$ from that of those from Vitoria de Santo Antão (V) and Curado (C), indicating that the araçás from Catuama are less succulent. However, contradictory results were obtained by Andrade et al. (1993), who evaluated araçá pêra (Psidium angulatum) and showed a moisture content of $85.85 \%$.

The total soluble solids (TSS) value is used in the food industry to maintain the quality control of the final product by controlling the process and ingredients, such as in sweets, juices, and nectar. It is also an index of the ripeness of some fruits and indicates the quantity of substances dissolved in the juice, most of which are sugars (GOMES et al., 2002). The principal 
sugars in fruits are glucose and fructose, which vary in proportion according to the species. According to the author above, fruits with seeds contain $8 \%$ to $15 \%$ of TSS. This information corroborates the values found in this study, which varied from $9.5 \%$ to $10 \%$ (Table 1).

The average weight of the fruits was $7.45 \mathrm{~g}$ (Table 1). A yield of $90 \%$ was verified after removing the sepals and maintaining the seeds. The latter were maintained with the objective of using the fruit to add value to culinary preparations.

When analyzing the first principal component (PC1) (Figure 2), which was 60.07\%, it was found that araçá originating from Curado showed positive values, characterized by greater moisture content and acidity, while the araçás from Catuama presented negative values, characterized by higher $\mathrm{pH}$ values. These results are summarized in Table 1.

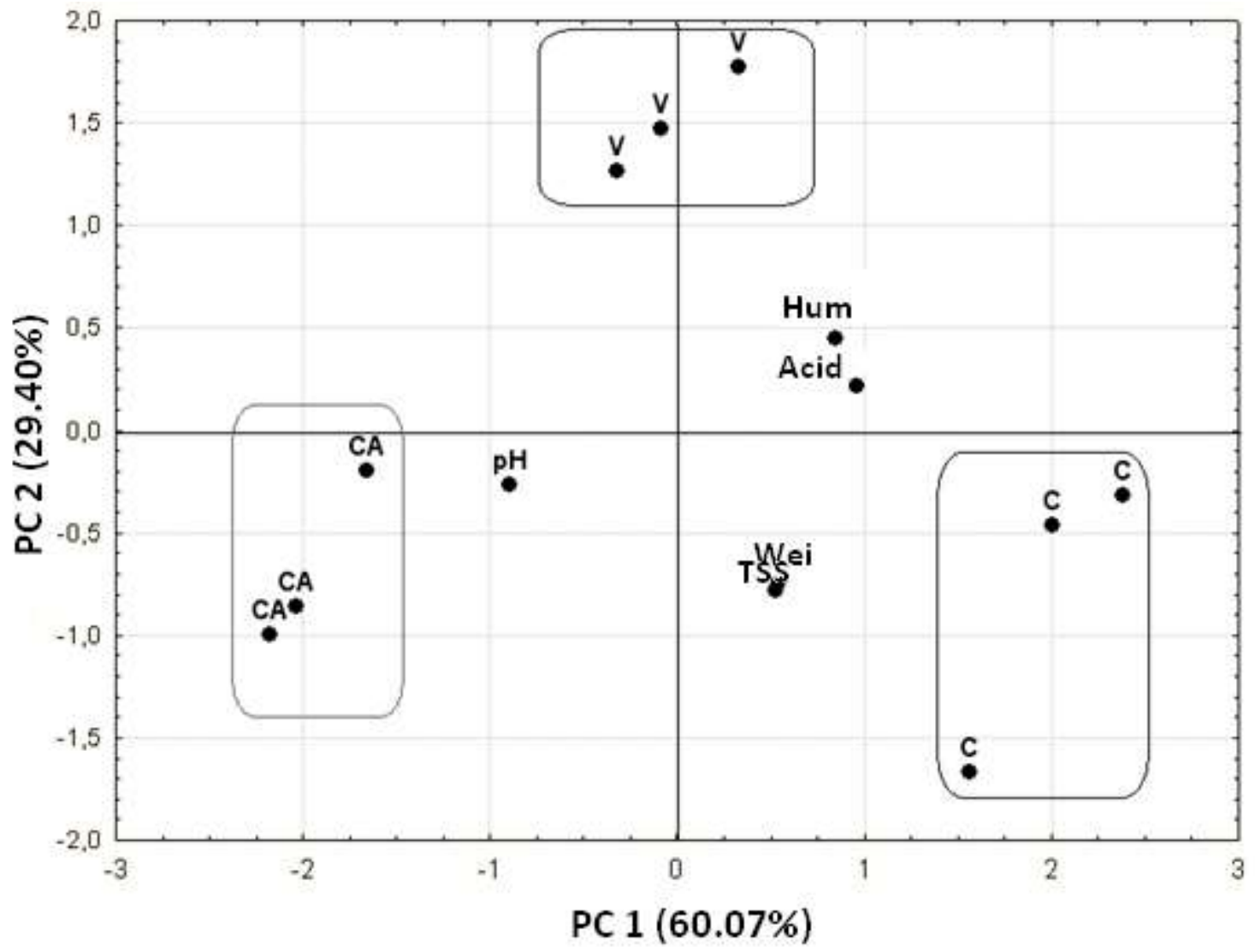

Figure 2: Bi-dimensional Principle Components Analysis of the physicochemical parameters and the originating locations of araçá. V - Vitória de Santo Antão; Ca - Catuama (coast); C - Curado; Hum - Humidity; Acid - Acidity; Wei - Weight; TSS - Total Soluble Solids

In relation to the second principal component (PC2), which represented $29.40 \%$ of the information, the araçás originating from Curado were found to be heavier and presenting a greater concentration of soluble solids; however, there was no significant difference between this location and the others ( $p>0.05)$, as shown in Table 1. 


\section{CONCLUSION}

The characteristics of the fruit under study give excellent support to the development of formulations using its pulp, which may be considered of commercial value with good potential for utilization in the gastronomy field. Principalmente porque são frutas nativas que precisam ser valorizadas para que não desapareçam da cultura loal

\section{REFERENCES}

ANDERSEN, O.; ANDERSEN, V. U. (1988). As frutas silvestres brasileiras, $1^{\circ}$ edição. Rio de Janeiro: GLOBO.

ANDRADE, J. S.; ARAGÃO, C. G.; FERREIRA, S. A. N. (1993). Caracterização física e química dos frutos de araçá pêra (Psidium acutangulum D.C.). Acta Amazônica, 23 (2-3), p. 213-217.

ARAÚJO, P. J.; NACHTIGALL, G. R.; HELBIG, V. E. (1996). Ponto de colheita e temperatura de armazenamento refrigerado de frutas de araçá (Psidium cattleyanum). In: Congresso Brasileiro de Fruticultura, Curitiba, PR. Resumos Londrina: IAPAR, p.56.

BeZerRA, J. E. F.; Lederman, I. E.; PEDROSA, A. C.; PEREIRA, R. C. A.; MELO NETO, M. L. (1990). Coleta e preservação de espécies frutíferas tropicais nativas e exóticas em Pernambuco. In: Simpósio Latino-Americano Sobre Recursos Genéticos De Espécies Hortícolas, Campinas, SP. Anais Fundação Cargil, n.1, p.140 - 147.

CAVALCANTE, P. B. (1976). Mirtácea. In: CAVALCANTE, P. B. Frutas comestíveis da Amazônia. Belém, INPA. P103 - 110.

CHISTÉ, R. C.; CARdOSO, R. C. D.; MOREIRA, D. K. T.; MOURA, J. A. A.; BRAGA, F. E. B. Caracterização físico-química, microbiológica e sensorial da geléia elaborada com araçá-boi (Eugenia stipitata McVaugh). Disponível em: http://artigocientifico.uol.com.br/uploads/artc 1164771983 88.pdf Acesso em: Setembro de 2008.

CLEMENT, C. R.; MULLER, C. H.; FLORES, W. B. C. (1982). Recursos Genéticos de espécies frutíferas nativas da Amazônia Brasileira. Acta Amazônica, v.12, n.4, p.677 - 695.

DONADIO, L. C. (2002). Frutas Brasileiras. Novos Talentos: Jaboticabal, 288p

EMBRAPA - CPACT. (1997). Cultivar de Araçá Irapuã. Boletim Informativo. 4p.

FRANZON, R. C. (2004). Caracterização de mirtáceas nativas do sul do Brasil. Rio Grande do Sul/RS, 99p. Dissertação (Mestre em Fruticultura de Clima Temperado), Faculdade de Agronomia Eliseu Maciel, Universidade Federal de Pelotas.

GOMES, P. M. A., FIGUEIRÊDO, R. M. F., QUEIROZ, A. J. M. (2002). Caracterização e isotermas de adsorção de umidade da polpa de acerola em pó. Revista Brasileira de Produtos Agroindustriais, 4 (2), p.157-165.

GOMES, R. P. Fruticultura Brasileira. São Paulo: Editora Nobel, 2007. 
GONZAGA NETO, L.; BEZERRA, J. E. F. (2000). Novas variedades brasileiras de frutas, Jaboticabal: Sociedade brasileira de fruticultura, p. $26-27$.

INSTITUTO ADOLFO LUTZ. (2005). Normas analíticas do Instituto Adolfo Lutz: métodos químicos e físicos para análises de alimentos. 3. ed. São Paulo: Instituto Adolfo Lutz.

KINUPP, V. F. (2014). Plantas Alimentícias não convencionais (PANC) no Brasil. Guia de identificação, aspectos nutricionais e receitas ilustradas. São Paulo Instituto Plantarum de estudos da Flora.

MANICA, I. (2000). Frutas nativas, silvestres e exóticas 1: técnica de produção e mercado. Porto Alegre: Cinco Continentes.

MARTINS-DA-SILVA, R. C. V. Identificação de espécimes botânicos. Embrapa Amazônia Ocidental. Belém - PA. Disponível em: <http://www.joinville.udesc.br/sbs/professores/arlindo/materiais/identifica_odeesp_cimes bot_nicos.pdf> Acesso em: Outubro de 2008.

MATIAS, L. Q. Coleta, herborização e o registro de material botânico. Taxonomia e Morfologia Vegetal. Universidade Federal do Ceará. Departamento de Biologia. Disponível em: $<$ http://www.biologia.ufc.br/monitoria/TaxoVeg/arquivos/Coleta\%20e\%20ident_angiosper. pdf> Acesso em: Outubro de 2008.

MORTON, J. (1987). Brazilian Guava. p. 365-367. In: Fruits of warm climates. Julia F. Morton, Miami, FL.

OLIVEIRA, G. R.; ASSIS, L. M.; RODRIGUEZ, A. F.; ZAMBIAZI, R. C. (2005). Elaboração de geléia de araçá e avaliação de sua aceitabilidade. Departamento de Ciência e tecnologia agroindustrial - FAEM/UFPel.

REIS SILVA, M.; Lemos L., Diracy B. C.; Gebrim S., G. ; De O. M., D. M. (2008, set). Caracterização química de frutos nativos do cerrado. Ciência Rural,.38(6), p.1790(4).

SILVA, J. A.; TASSARA, H. (1996). Frutas no Brasil. São Paulo: Empresa das Artes.

VOLTOLINI, J. A. \& FACHINELLO, J. C. (1996). Influência do sombreamento em plantas matrizes para produção de mudas de araçazeiro (Psidium cattleyanum Sabine) multiplicadas por estacas no inverno. Congresso Brasileiro de Fruticultura, 14. 1996. Curitiba, PR. Resumos Londrina: IAPAR. 561p.; p.58. 